\title{
Spontaneous bacterial peritonitis in patients with liver cirrhosis and ascites - New insights using cytokine and cytokine receptor analysis in ascites
}

TILO ANDUS, MD, JÜRGEN SCHÖLMERICH, MD

T ANDUS, J SCHÖLMERICH. Spontaneous bacterial peritonitis in patients with liver cirrhosis and ascites - New insights using cytokine and cytokine receptor analysis in ascites. Can J Gastroenterol 1992;6(3):141-146. The cloning and expression of cytokines and their receptors has led to the development of sensitive and specific immunoassays for their determination in biological fluids such as ascites. Using such assays, the cytokines IL-1 $\beta, \mathrm{IL}-6, \mathrm{IL}-8$ and TNF $\alpha$ were found in ascitic fluid samples of patients with infected and malignant ascites. IL-6 was found in high concentrations even in ascites samples of not infected hepatic ascites. In addition, high concentrations of soluble TNF receptor $\mathrm{p} 55$ and $\mathrm{p} 75$ were found in ascites. IL-1 and IL-6 concentrations were increased in infected ascites while concentrations of both TNF receptors were increased in infected and malignant ascites, indicating that the combined measurement of cytokines and cytokine receptors may be helpful for the differential diagnosis of ascites (allowing the differentiation among infected, malignant and uncomplicated hepatic ascites). High concentrations of cytokines and soluble cytokine receptors in ascites, their increase during infection and malignancy, and their high potency to regulate inflammatory processes and other mediators indicate that they play an important role in the pathogenesis of ascites. Thus, measuring cytokines and soluble cytokine receptors in ascitic fluid opens a new window to study the pathogenesis of ascites and eventually may lead to the development of new methods of medical treatment of ascites using specific cytokine antagonists. (Pour résumé, voir page 142)

Key Words: Ascites, Cytokines, Interleukin, Soluble cytokine receptors, Spontaneous bacterial peritonitis, Tumour necrosis factor

Department of Internal Medicine I, University of Regensburg, Franz Josef Strauss Allee, W-8400 Regensburg, Germany

Correspondence and reprints: Professor Dr J Schölmerich, Medizinische Klinik und Poliklinik 1, Universität Regensburg Franz Josef Strauss Allee 11, W-8400 Regensburg, Germany.

Telephone 0941/944-7001, Fax 0941/944-7002

Received for publication April 10, 1992. Accepted May 11, 1992
A SCITES IS A FREQUENT COMPLI. cation of severe liver diseases with portal hypertension and of malig. nant tumours metastatic to the peritoneum $(1,2)$. While malignant ascites are rarely infected, patients with hepatic ascites frequently develop spontaneous bacterial peritonitis; often without any obvious primary source of infection (3). The prevalence of spontaneous bacterial peritonitis in hospitalized patients with hepatic cirrhosis and ascites is approximately 15\%. Spontaneous bacterial peritonitis is a severe complication with a mortality rate of more than $50 \%$ and a high rate of recurrence (approximately 70\% per year). Typical symptoms of spontaneous bacterial peritonitis are abdominal pain, fever, hepatic encephalopathy or unexplained clinical deterioration. Bacteria cultured from infected ascites usually represent the normal aerobic flora of the gut, but due to the low number of bacteria in ascites (usually one $/ \mathrm{mL}$ ), diagnosis of infection by culture of ascitic fluid is often difficult or not possible (4).

There are several predisposing factors for the manifestation of sponta- 


\section{Péritonite bactérienne spontanée chez des patients présentant une cirrhose et de l'ascite: nouvelles approches à base de cytokines et analyse des récepteurs de cytokines dans l'ascite}

RÉSUMÉ: Le clonage et l'expression des cytokines et de leurs récepteurs ont mené à la mise au point d'essais immunologiques sensibles et spécifiques pour leur détection dans les liquides biologiques tels que l'ascite. À l'aide de telles épreuves, les cytokines IL-1 $\beta$, IL-6, IL-8 et TNF $\alpha$ ont été décelées dans des échantillons d'ascite chez des patients présentant une ascite infectée et maligne. L'IL-6 a été notée en concentration élevée, même dans des échantillons non infectés. En outre, des concentrations élevées de récepteurs de TNF solubles p 55 et p 75 ont été trouvées dans l'ascite. Des concentrations d'IL-1 et d'IL-6étaient élevées dans l'ascite infectée alors que des concentrations des récepteurs de TNF se trouvaient augmentés dans l'ascite infectée et maligne, ce qui donne à penser que la mesure combinée des cytokines et de récepteurs de cytokines peut se révéler utile dans le diagnostic différentiel de l'ascite (en permettant la différenciation entre l'ascite hépatique infectée maligne et non compliquée). Des concentrations élevées de cytokines et des récepteurs solubles de cytokines dans l'ascite, leur augmentation au cours de l'infection et de la malignité et leur potentiel élevé à régler le processus inflammatoire et d'autres médiateurs indiquent qu'ils jouent un rôle important dans la pathogenèse de l'ascite. Ainsi, la mesure des cytokines et des récepteurs solubles de cytokines dans l'ascite ouvre une nouvelle avenue pour l'étude de la pathogenèse de l'ascite et pourra mener à la mise au point de nouvelles thérapeutiques médicales contre l'ascite à l'aide d'antagonistes spécifiques de cytokines.

neous bacterial peritonitis: an impaired liver function weakens the immune system locally and systemically (5-7); intra- and extrahepatic shunting leads to a decreased clearance of bacteria by the hepatic reticuloendothelial system and to recurrent systemic bacteriemia; and patients with low ascitic total protein concentrations (8) and low opsonic activity in ascitic fluids and serum have a higher risk for spontaneous bacterial peritonitis $(5,7,9)$.

Cytokines are important mediators playing a key role in immune system regulation and synthesis of hepatic acute phase proteins such as complement factors (10-12). Most cytokines are glycoproteins with a molecular mass below 80,000 D. Cytokines usually act in picomolar concentrations via specific, high affinity cell surface receptors. Cells involved in cytokine synthesis include: blood cells such as monocytes, lymphocytes and platelets; stromal cells such as fibroblasts, endothelial cells and smooth muscle cells; and parenchymal cells such as keratinocytes and hepatocytes. Most cytokines may not only be produced by a variety of cell types as a reaction to different stimuli, but also may have numerous biological effects on several different target cells.

Molecular cloning of cytokines and their receptors led to the development of sensitive and specific assays which facilitated their measurement in blood and other body fluids such as ascites. The following review summarizes the current knowledge about cytokines and their receptors in ascites and discusses possible clinical applications of their measurement.

\section{CYTOKINES IN ASCITES}

Although serum concentrations of cytokines have been determined in patients with liver diseases for several years (13-22), cytokines only recently have been detected in ascites. In patients with hepatic ascites the cytokines found in ascitic fluid were interleukin(IL)-1及 (23), IL-6 (23-29), IL-8 (23) and tumour necrosis factor alpha (TNF $\alpha)(23-25,28)$. IL- 6 was by far the most abundant cytokine in ascites, with concentrations ranging between 200 and $100,000 \mathrm{pg} / \mathrm{mL}(23-27,29)$. In contrast, IL-1 $\beta$ was undetectable in most ascitic fluid samples and only was found in culture-positive ascites (23). Also, IL- 8 and TNF $\alpha$ were only detectable in some ascitic fluid samples (23).

Ascitic concentrations IL-1 $\beta$ (23), IL-6 (23-27,29) and TNF $\alpha$ (23-25) were higher in patients with spontaneous bacterial peritonitis than in patients with uninfected hepatic ascites, and were found to be reduced to lower concentrations after successful antibiotic treatment (23-25); finding could be used to separate culture-positive from culture-negative ascites. IL$1 \beta$ and IL- 6 were found to separate the two groups with a diagnostic accuracy of $98 \%$ at cutoff levels of 10 and 8000 $\mathrm{pg} / \mathrm{mL}$. Interestingly, patients with the culture-negative variant of spontaneous bacterial peritonitis had no elevated concentrations of cytokines.

In six patients without peritonitis, concentrations of IL- 6 and TNF $\alpha$ were only slightly higher in ascites than in serum $(24,25)$; however, in 21 patients without peritonitis, ascites concentrations were about 100 -fold higher than corresponding plasma concentrations $(23,26,27,29)$. This ratio was 500 -fold higher in patients with peritonitis. These findings strongly suggest that IL. 6 is produced locally in the peritoneal cavity. Furthermore, since half of the ascites fluid shifts back and forth every hour through the large capillary bed of the splanchnic peritoneum $(31,32)$ and since IL-6 rapidly diffuses into the plasma (33) (where it is cleared within a few minutes [34]), intraperitoneal production of IL-6 must be continuously high to maintain the high concentrations found in all patients with ascites. This, in turn, suggests that there is continuous stimulation of peritoneal inflammatory cells even in patients with uncomplicated ascites. Among these cells, peritoneal macrophages probably are the most important source of IL-6 production since isolated peritoneal macrophages from patients with ovarian carcinoma (35) and from mice (36. 38) have been shown to release IL-1 ( 35 , $37,38)$, IL-6 $(35,38)$ and TNF $\alpha(36,37)$.

Lipopolysaccharides presumably are the major stimulating factor of cytokine synthesis in hepatic ascites since they strongly stimulate cytokine synthesis $(10,39)$, and high lipopolysac- 
charide levels have been found frequently in ascites $(79 \%)$ and plasma of cirrhotic patients with ascites $(76 \%)$ (40). The Gram-negative flora of the gut provides a huge pool of lipopolysaccharides which may enter systemic circulation and ascitic fluid (when hepatic clearance is impaired by portal systemic shunting and there is decreased Kupffer cell function as during liver disease) $(41,42)$. In addition, evidence for lymphatic uptake of lipopolysaccharides and even viable Gram-negative bacteria has been shown (43-45)

\section{ROLE OF CYTOKINES IN ASCITES}

Since cytokines are very potent inflammatory mediators affecting a broad range of effector cells, the presence of cytokines in ascitic fluid may have a great impact on the pathophysiology of ascites. Increased ascitic cytokine concentrations during spontaneous bacterial peritonitis indicate that they may act locally as part of the host's defence system against infectious agents. For example, IL-8 induces migration and activation of neutrophils (46), and IL-1 (47), IL-6 (10) and TNF $\alpha$ (48) increase $\mathrm{T}$ and $\mathrm{B}$ cell activity and nonspecific resistance to infection. High concentrations of the anti-inflammatory cytokine IL-6 (found in all ascites samples) may protect the host from the potentially dangerous systemic effects of high concentrations of pro-inflammatory cytokines (ie, IL-1, IL-8 and TNF $\alpha$ ), since IL-6 can inhibit the synthesis of IL -1 and TNF $\alpha$ in mononuclear cells $(49,50)$.

Besides their protective action, an animal study (51) showed that cytokines may be involved in ascites formation. Cytokines may induce ascites formation by several mechanisms. Cytokines such as IL-1, interferon- $\gamma$ and TNF $\alpha$ induce the production of nitrogen oxides in macrophages and endothelial cells $(52,53)$ which leads to peripheral vasodilation and subsequent fluid retention. Furthermore, cytokines increase vascular permeability resulting in the transudation of plasma from the circulation into extravascular space $(51,54)$.

Diffusion of cytokines IL-1, IL-6, IL-
8 and TNF $\alpha$ into the systemic circulation can cause clinical signs such as fever, pain, wasting, hypotension and septic shock and can contribute to the clinical picture of spontaneous bacterial peritonitis.

\section{SOLUBLE CYTOKINE RECEPTORS}

Cytokines act specifically on target cells by binding to specific surfacebound receptors which trigger second messenger mechanisms that lead to changes in the transcription of cytokine-regulated proteins. In addition to the surface-bound receptors, there are soluble cytokine receptors.

Elevated concentrations of low affinity soluble IL-2 receptors have been found in the sera of patients with hepatitis B (55), autoimmune hepatitis (56), a wide variety of other diseases (57) and after liver transplantation (58). Soluble receptors for IL-6 and interferon- $\gamma$ can be purified from normal human urine (59). The cloning and expression of the murine IL-7 receptor led to detection of a soluble form which was secreted into the medium by transfected cells (60). Soluble inhibitory forms of IL-1 (61, 62) and TNF (63-66) have been found in human serum and urine. Recently, elevated serum concentrations of soluble TNF receptors were found in patients with burns or renal failure, but no increase was found in patients with chronic polyarthritis (67).

Few data exist about soluble cytokine receptors in ascites. Soluble, high affinity IL-4 receptors are present in the ascites fluid, serum and urine of normal mice (68). Soluble IL-4 receptor concentration was reduced in severe combined immunodeficiency mice (68).

High concentrations of soluble TNF receptor $\mathrm{p} 55$ and $\mathrm{p} 75$ were detected in all ascites and plasma samples of 34 patients with hepatic infected, noninfected and malignancy-related ascites $(28,30)$. In all patients, molar TNF receptor concentrations were about 500 -fold higher than molar TNF $\alpha$ concentrations in the ascites; serum samples ranged from 2.5 to $35 \mathrm{ng} / \mathrm{mL}$ in ascites and from 1.5 to $60 \mathrm{ng} / \mathrm{mL}$ in serum. The mean concentrations of TNF receptor p55 and p75 were elevated about 2.5 and 3.5 times, respectively, in both infected hepatic and malignant ascites compared with uncomplicated hepatic ascites. The ascites TNF receptor concentrations were similar in patients with infected and malignant ascites. Plasma concentrations of TNF receptor p55 and p75 were elevated in these subgroups, but showed a large overlap with the noninfected hepatic ascites samples.

The concentrations of TNF receptor p55 were higher than TNF receptor p75 in ascites, whereas TNF receptor p75 was higher in plasma concentrations. The elevated concentrations of TNF receptor p $55(24.2 \pm 15.2 \mathrm{ng} / \mathrm{mL})$ and p75 $(20.2 \pm 14.4 \mathrm{ng} / \mathrm{mL})$ found in infected ascitic fluid decreased to lower levels $(10.7 \pm 1.89$ and $7.50 \pm 1.80$ $\mathrm{ng} / \mathrm{mL}$, respectively) after successful antibiotic treatment.

High concentrations of soluble cytokine receptors, which increase or decrease during the course of disease, raise several questions: what is the source of the soluble receptors?; by what mechanisms are the receptors released?; and how is the synthesis and release of the cytokine receptors regulated?

\section{ROLE OF CYTOKINE RECEPTORS IN ASCITES}

High concentrations of soluble cytokine receptors suggest an important immunoregulatory role. The large amounts of soluble TNF receptors (500-fold molar excess above TNF $\alpha$ ), for example, strongly impair TNF bioavailability in ascites and plasma. Soluble IL-2 receptors found in sera of patients with inflammatory diseases may have similar immunomodulating effects on the activation of $\mathrm{T}$ lymphocytes.

These high receptor concentrations may be an important, beneficial part of the immunological regulatory mechanisms by minimizing tissue destruction caused by excessive cytokine release of inflammatory cells during defence against infectious agents and other injuries. Although cytokines usually contribute to protection of the organism against infectious agents and to healing from injury, their actions may become pernicious in certain pathological situations (eg, septic shock, a more 

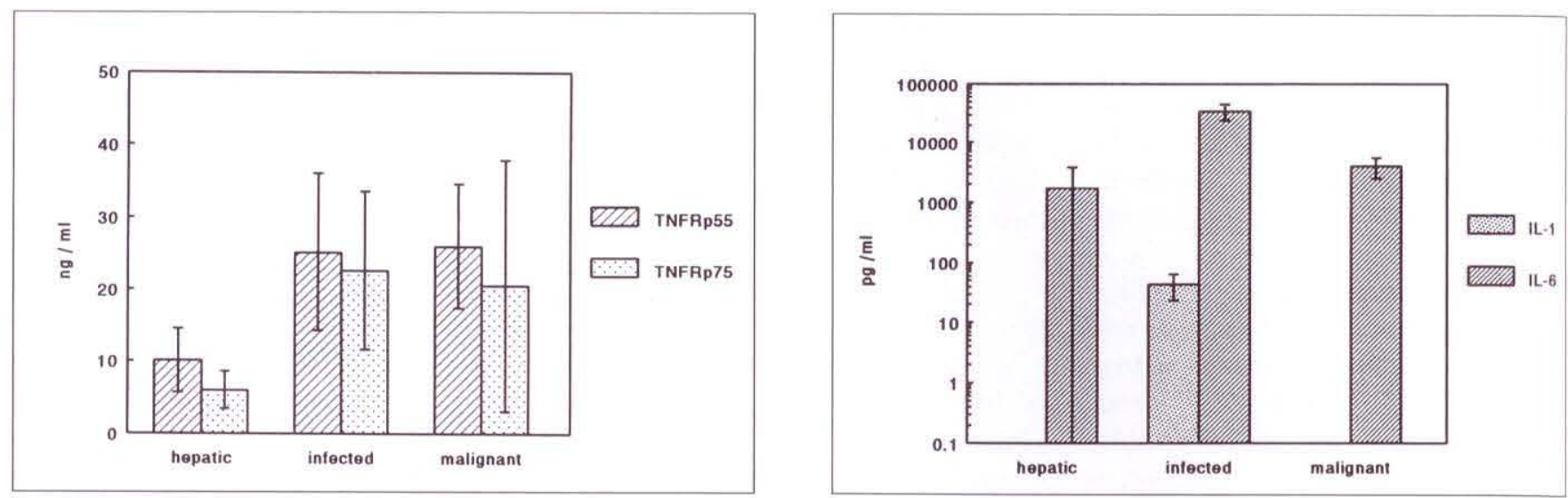

Figure 1) Concentrations of interleukin (IL) - 1, IL-6, tumour necrosis factor (TNF) receptor p55 and p 75 measured by enzyme-linked immunosorbent assay, in ascites of patients with hepatic, infected and malignant ascites. Data are expressed as means \pm standard deviation

severe destruction results than that induced by the pathogen itself). Regulators of the biological activity of cytokines, such as the detected TNF receptors, which counteract potentially harmful effects of TNF are therefore essential to maintain physiological homeostasis during infection and malignancy.

On the other hand, release of TNF receptors in malignant ascites may be a defensive mechanism of malignant cells to protect them from cytotoxic effects of TNF. High concentrations of TNF receptors in malignant ascites which also can strongly diminish bioavailability of locally administered TNF in the treatment of cancer patients (65) - should be considered in such clinical trials.

\section{CLINICAL APPLICATIONS}

The finding of cytokines and soluble cytokine receptors in ascitic fluid is an important step to understand the pathophysiology of ascites. It also may lead to several clinical applications. The first studies suggest that measure-

\section{REFERENCES}

1. Conn HO. The diagnosis and examination of ascitic fluid. In: Beker $\mathrm{S}$, ed. Diagnostic Procedures in the Evaluation of Hepatic Diseases. New York: Alan R Liss, 1983:529-65.

2. Rocco VK, Ware AJ. Cirrhotic ascites. Ann Intern Med 1986;105;573-85.

3. Runyon BA. Spontaneous bacterial peritonitis: An explosion of information. Hepatology 1988;8:171-5.

4. Hoefs JK. Spontaneous bacterial peritonitis: Prevention and therapy. ment of cytokines and soluble cytokine receptors can help differentiate between ascites of different origins; for example, of IL-1 $\beta$ and IL- 6 in the ascitic fluid separated with a diagnostic accuracy of $98 \%$ between culture-positive and culture-negative spontaneous bacterial peritonitis (this can be especially important when antibiotic treatment is interfering with diagnosis by bacterial cultures) $(23,27,29,30)$. Ascitic fluid concentrations of both TNF receptor p55 and p75 differentiated with diagnostic accuracies of 94 and $89 \%$, respectively, between patients with malignant or infected ascites and patients with uncomplicated hepatic ascites.

Although IL-1 $\beta$ and IL-6 did not separate between uncomplicated hepatic ascites and malignant ascites, and soluble TNF receptor concentrations did not differ between infected and malignant ascites, the combination may be helpful. Whereas in infected ascites, IL-1 $\beta$, IL- 6 and both soluble TNF receptors are higher than in uncomplicated ascites, in malignant as-

Hepatology 1990;12:776-81.

5. Runyon BA, Morrisey RL, Hoefs JC, Wyle FA. Opsonic activity of human ascitic fluid: A potentially important protective mechanism against spontaneous bacterial peritonitis. Hepatology 1985;5:634-7.

6. Rajkovic IA, Williams R. Abnormalities of neutrophil phagocytosis, intracellular killing and metabolic activity in alcoholic cirrhosis and hepatitis. Hepatology $1986 ; 6: 252-62$. cites only the concentrations of the soluble TNF receptor are elevated (Fig. ure 1). Although these first results are very promising, further studies are re. quired for confirmation. The inclusion of other cytokines and soluble cytokine receptors in future studies may detect additional helpful parameters for differential diagnosis.

The bacterial culture of ascites fluid remains the gold standard for the diag. nosis of spontaneous bacterial peritonitis, but measurement of cytokines also may be helpful when patients have been pretreated with antibiotics and to study the response to antibiotic treatment.

The study of cytokines and their soluble receptors will lead to a better understanding of the pathophysiology and pathogenesis of ascites. If cytokines play an essential role in the pathogenesis of ascites, an understanding of their actions probably will lead to develop. ment of new therapies using specific cytokines or cytokine antagonists and may help assess the prognosis of patients with ascites.

7. Runyon BA. Patients with deficient ascitic fluid opsonic activity are predisposed to spontaneous bacterial peritonitis. Hepatology 1988;8:632-5.

8. Runyon BA. Low-proteinconcentration ascitic fluid is predisposed to spontaneous bacterial peritonitis. Gastroenterology 1986;91:1343-6.

9. Tito L, Rimola A, Gines P, Llach J, Arroyo V, Rodes A. Recurrence of spontaneous bacterial peritonitis in cirrhosis: Frequency and predictive 
factors. Hepatology 1988;8:27-31.

10. Heinrich PC, Castell JV, Andus T. Interleukin- 6 and the acute phase response. Biochem J 1990;265:621-36.

11. Andus T, Bauer J, Gerok W. Effect of cytokines on the liver Hepatology 1991;13:364-75.

12. Peters M, Vierling J, Gershwin ME, Milich D, Chisari FV, Hoofnagle JH. Immunology and the liver. Hepatology 1991;13:977-94

13. McClain CJ, Cohen DA, Dinarello CA, Cannon JG, Shedlofsky SI, Kaplan AM. Serum interleukin-1 (1L-1) activity in alcoholic hepatitis. Life Sci 1986;39:1479-85.

14. Anastassakos C, Alexander GIM, Wolstencroft RA, et al. Interleukin-1 and interleukin-2 activity in chronic hepatitis B virus infection. Gastroenterology 1988;94:999-1005.

15. Minuk GY, LaFreniere R. Interleukin-1 and interleukin-2 in chronic type B hepatitis. Gastroenterology 1988;94:1094-6.

16. Deviere J, Content J, Denys C, et al. High interleukin-6 serum levels and increased production by leukocytes in alcoholic liver cirrhosis. Correlation with $\operatorname{Ig} \mathrm{A}$ serum levels and lymphokines production. Clin Exp Immunol 1989;77:221-5

17. McClain CJ, Cohen DA. Tumor necrosis factor in alcoholic hepatitis. Gastroenterology 1989;97:1056-7.

18. Yoshioka K, Kakumu S, Arao M. Tsutsumi Y, Inoue M. Tumor necrosis factor $\alpha$ production by peripheral blood mononuclear cells of patients with chronic liver disease. Hepatology 1989;10:769-73.

19. Müzes G, Deak G, Lang L. GonzalezCabello R, Gergely P, Feher J. Depressed monocyte production of interleukin- 1 and tumor necrosis factor-alpha in patients with alcoholic liver cirrhosis. Liver 1989;9:302-6.

20. Bird GLA, Sheron N, Goka AKJ, Alexander GJ, Williams RS. Increased plasma tumor necrosis factor in severe alcoholic hepatitis. Ann Intern Med 1990;112:917-20.

21. Felver ME, Mezey E, McGuire M, et al Plasma tumor necrosis factor a predicts decreased long/term survival in severe alcoholic hepatitis. Alcoholism. Clin Exp Res 1990;77:221-5.

22. Khoruts A, Stahnke L, McClain CJ, Logan G, Allen JI. Circulating tumor necrosis factor, interleukin-1 and interleukin-6 concentrations in chronic alcoholic patients. Hepatology 1991;13:267-76

23. Andus T, Gross V, Holstege A, et al. Evidence for the local production of interleukin-1 $\beta$, interleukin-6, interleukin- 8 and tumor necrosis factor $a$ in cirrhotic and malignant ascites.
Hepatology 1991;14:97A. (Abst)

24. Deviere J, Content J, Dupont E. Intraperitoneal secretion of TNF $\alpha$ and IL-6 during spontaneous bacterial peritonitis. Gastroenterology 1990;98:A582. (Abst)

25. Deviere J, Content J, Crusiaux A, Dupont E. IL- 6 and TNF $\alpha$ in ascitic fluid during spontaneous bacterial peritonitis. Dig Dis Sci 1991;36:123-4 (Lett)

26. Andus T, Gross V, Ott M, et al. Hohe Interleukin-6-Konzentrationen im infizierten und nicht infizierten Aszites. Latente Peritonitis bei asymptomatischen Patienten? Z Gastroenterol 1991:28:682. (Abst)

27. Andus T, Gross V, Weber M, Ott M, Gerok W, Schölmerich J. High interleukin-6 levels in ascites with and without spontaneous peritonitis. Gastroenterology 1991;100:A714. (Abst)

28. Andus T, Gross V, Holstege A, et al. Presence of high concentrations of soluble tumor necrosis factor receptor: (p55 and p75 in ascites. Hepatology. (In press)

29. Andus T, Gross V, Holstege A, Schölmerich J. High interleukin-6 concentrations in hepatic ascites. Dig Dis Sci. (Lett) (In press)

30. Andus T, Gross V, Holstege A, et al. Interleukin-1, interleukin-6, interleukin-8 and tumor necrosis factor ce in ascites. Evidence for local production of IL-6 and raised levels of $\mathrm{IL}-\mathrm{Im}$ and $\mathrm{IL}-6$ in peritonitis. Dig Dis Sci. (In press)

31. Prentice TC, Siri W, Joiner EE. Quantitative studies of ascitic fluid circulation with tritium-labeled water Am J Med 1952;13:668-73.

32. Birkenfeld LW, Leibman J, O'Meara MP. Total exchangeable sodium, total exchangeable potassium, and total body water in edematous patients with cirrhosis of the liver and congestive heart failure. J Clin Invest 1958;37:687-98.

33. Geiger T, Andus T, Klapproth J, Hirano T, Kishimoto T, Heinrich PC. Induction of rat acute-phase proteins by interleukin-6 in vivo. Eur J Immunol 1988;18:717-21.

34. Castell JV, Geiger T, Gross V, et al. Plasma clearance, organ distribution and target cells of interleukin-6/ hepatocyte stimulating factor in the rat. Eur J Biochem 1988;177:357-61

35. Erroi A, Sironi M, Chiaffarino F, Chen ZG. Mengozzi M, Mantovani A. IL-1 and IL- 6 release by tumor-associated macrophages from human overian carcinoma. Int J Cancer 1989;44:795-801.

36. Remick DG, Streeter RM, Eskandari MK, et al. Role of tumor necrosis factor-alpha in lipopolysaccharideinduced pathologic alterations. Am J Pathol 1990;136:49-60.

37. Hart PH, Cooper RL, Finlay-Jones J]. IL-4 suppresses IL-1 heta, TNF-alpha and PGE2 production by human peritoneal macrophages. Immunology 1991:72:344-9.

38. Gong JH, Renz H, Nain M, Gemsa D. Interleukin 1 as a tumor cytostatic mediator released from tumour ascites. treated macrophages. Immunobiology 1988;177:339-51.

39. Northoff H, Andus T, Tran-Thi T-A, et al. The inflammation mediators interleukin-I and hepatocytestimulating factor are differently regulated in human monocytes. Eur J Immunol 1987;17:707-11.

40. Tarao K, So K, Moroi T, et al. Detection of endotoxin in plasma and ascitic fluid of patients with cirrhosis: its clinical significance. Gastroenterology 1977;73:539-42.

41. Prytz J, Holst-Christensen J, Komer D. Portal venous and systemic endotoxemia in patients without liver disease and systemic endotoxemia in patients with liver cirrhosis. Scand I Gastroenterol 1976;11:857-63.

42. Lumbsen, AB, Henderson M, Kutner $\mathrm{MH}$. Endotoxin levels measured by a chromogenic assay in portal, hepatic and peripheral venous blood in patients with ciffhosis. Hepatology 1988;8:232-6.

43. Olofson O, Nylander G, Olsson P. Endotoxin: Routes of transport in experimental peritonitis Am J Surg 1986;151:443-6.

44. Daniele R, Singh H, Appert HE, Paireent FW, Howar JM. Lymphatic absorption of intraperitoneal endotoxin in the dog. Surgery 1970;67:484-7.

45. Runyon BA, Squier SU. Translocation of gut bacteria of ciffhotic rats to mesenteric lymph nodes may partially explain the pathogenesis of spontaneous bacterial peritonitis. Hepatology 1991;14:91A. (Abst)

46. Baggiolini M, Walz A, Kunkel SL. Neutrophil-activating peptide-1/ interleukin-8, a novel cytokine that activates neutrophils. J Clin Invest 1989;84:1045-9.

47. Dinarello CA. Interleukin-1 and interleukin-1 antagonism. Blood 1977:1627-52.

48. Jäattrelä M. Biology of disease. Biologic activities and mechanisms of action of tumor necrosis factor-a/cachectin. Lab Invest 1991;64:724-42.

49. Aderka D, Le J, Vilcek J. IL-6 inhibits lipopolysaccharide-induced tumor necrosis factor production in cultured human monocytes, U937 cells, and in mice. I Immunol 1989; 143:3517-23. 
50. Schindler R, Mancilla J, Endres S, Ghorbani R, Clark SC, Dinarello CA. Correlations and interactions in the production of interleukin-6 (IL-6), IL-1, and tumor necrosis factor (TNF) in human mononuclear cells: IL-6 suppresses IL-1 and TNF. Blood 1990;75:40-7.

51. Guarner F, Wallace JL, MacNaughton WK, Ibbotson GC, Arroyo V, Rodes ]. Endotoxin-induced ascites formation in the rat: Partial mediation by platelet-activating factor. Hepatology 1989;5:788-94.

52. Kilbourn RG, Gross SS, Jubran A, et al. NG-methyl-L-arginine inhibits tumour necrosis factor-induced hypotension: Implications for the involvement of nitric oxide. Proc Natl Acad Sci USA 1990;87:3629-32.

53. Kilbourn RG, Belloni P. Endothelial cell production of nitrogen oxides in response to interferon gamma in combination with tumor necrosis factor, interleukin-1, or endotoxin. J Natl Cancer Inst 1990;82:772-6.

54. Kubes P, Suzuki M, Granger DN. Modulation of PAF-induced leukocyte adherence and increased microvascular permeability. Am J Physiol 1990;259:G859-64.

55. Alberti A, Chemello L, Fattovich G, et al. Serum levels of soluble interleukin-2 receptors in acute and chronic viral hepatitis. Dig Dis Sci 1989;34:1559-63.

56. Rubin LA, Nelson DL. The soluble interleukin-2 receptor: Biology, function, and clinical application. Ann Intern Med 1990;113:619-27.

57. Lobo-Yeo A, Mieli-Vergani G, Mowat AP, Vergani D. Soluble interleukin-2 receptors in autoimmune chronic active hepatitis. Gut 1990;31:690-3.

58. Adams DH, Wang L, Hubscher SG, Elias E, Neuberger JM. Soluble interleukin-2 receptors in serum and bile of liver transplant recipients. Lancet $1989 ; \mathrm{i}: 469-71$.

59. Novick D, Engelmann H, Wallach D, Rubinstein M. Soluble cytokine receptors are present in normal human urine. J Exp Med 1989;170:1404-9.

60. Goodwin RG, Friend D, Ziegler SF, et al. Cloning of the human and murine interleukin-7 receptors: Demonstration of a soluble form and homology to a new receptor superfamily. Cell 1990;60:941-51.

61. Seckinger P, Williamson K, Balavoine JF, et al. A urine inhibitor of interleukin I activity effects both interleukin $l \alpha$ and $1 \beta$ but not tumour necrosis factor ce. J Immunol 1987;139:1541-5.

62. Seckinger P, Lowenthal JW, Williamson K, Dayer J-M, Shaw AR, Schmeissner U.
A urine inhibitor of interleukin I activity that blocks ligand binding. J Immunol 1987;139:1546-9.

63. Olsson I, Lantz M, Nilsson E, et al. Isolation and characterization of a tumor necrosis factor binding protein from urine. Eur J Haematol 1989;42:270-5.

64. Seckinger P, Isaaz S, Dayer J-M. Purification and biologic characterization of a specific tumor necrosis factor a inhibitor. J Biol Chem 1989;265:11966-73.

65. Engelmann H, Novick D, Wallach D. Two tumor necrosis factor-binding proteins purified from human urine. J Biol Chem 1990;265:1531-6.

66. Gatanaga T, Lentz R, Mansunuka I, et al. Identification of TNF-LT blocking factor(s) in serum and ultrafiltrates of human cancer patients. Lymphokine Res 1990;9:225-9.

67. Adolf GR, Apfler 1. A monoclonal antibody-based enzyme immunoassay for quantitation of human tumor necrosis factor binding protein $l$, a soluble fragment of the $60 \mathrm{kDa}$ TNF receptor. J Immunol Meth 1991;143:127-36.

67. Fernandez-Botran R, Vitetta E. A soluble, high affinity, interleukin-4. binding protein is present in the biological fluids of mice. Proc Natl Acad Sci 1990;87:4202-6. 


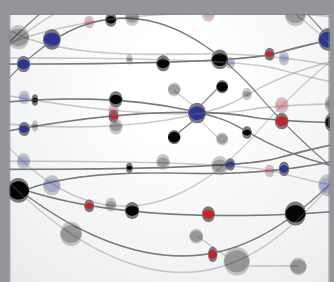

The Scientific World Journal
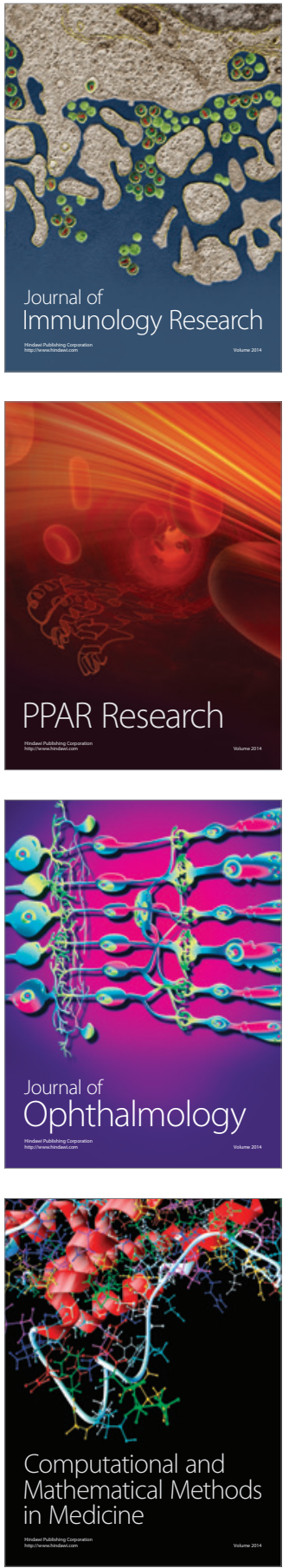

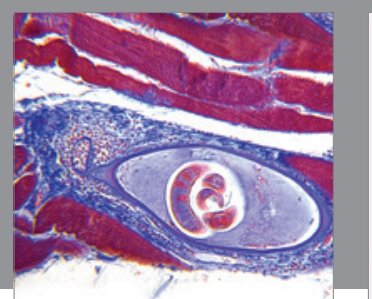

Gastroenterology Research and Practice

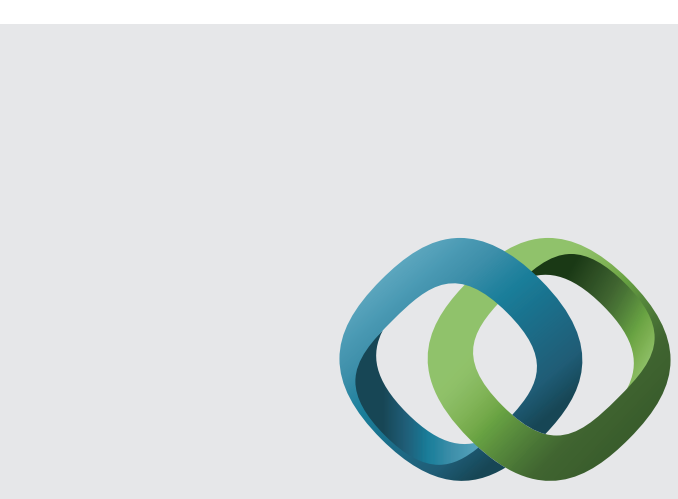

\section{Hindawi}

Submit your manuscripts at

http://www.hindawi.com
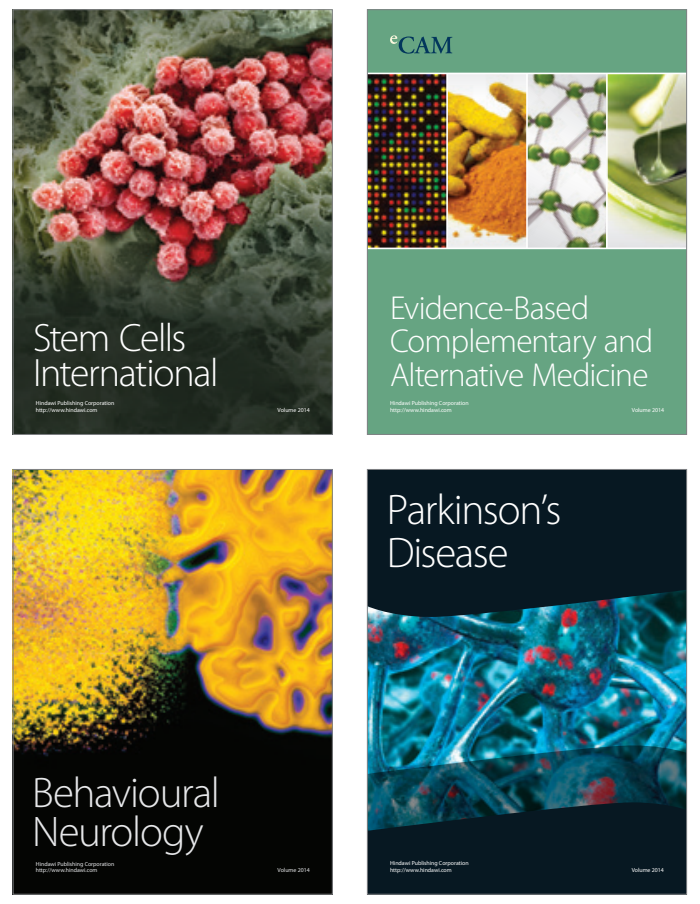
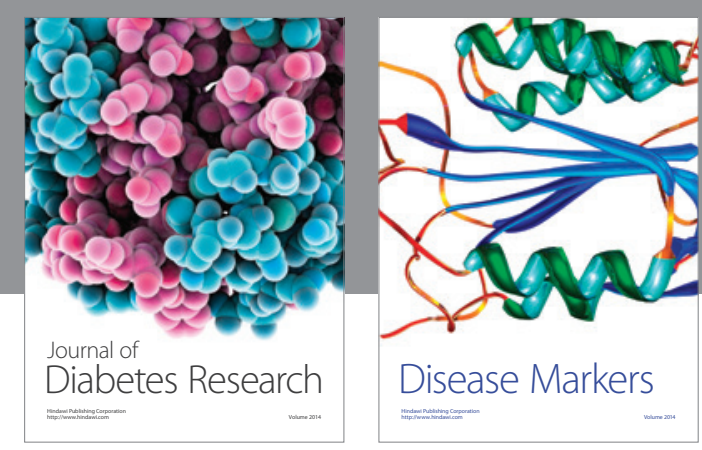

Disease Markers
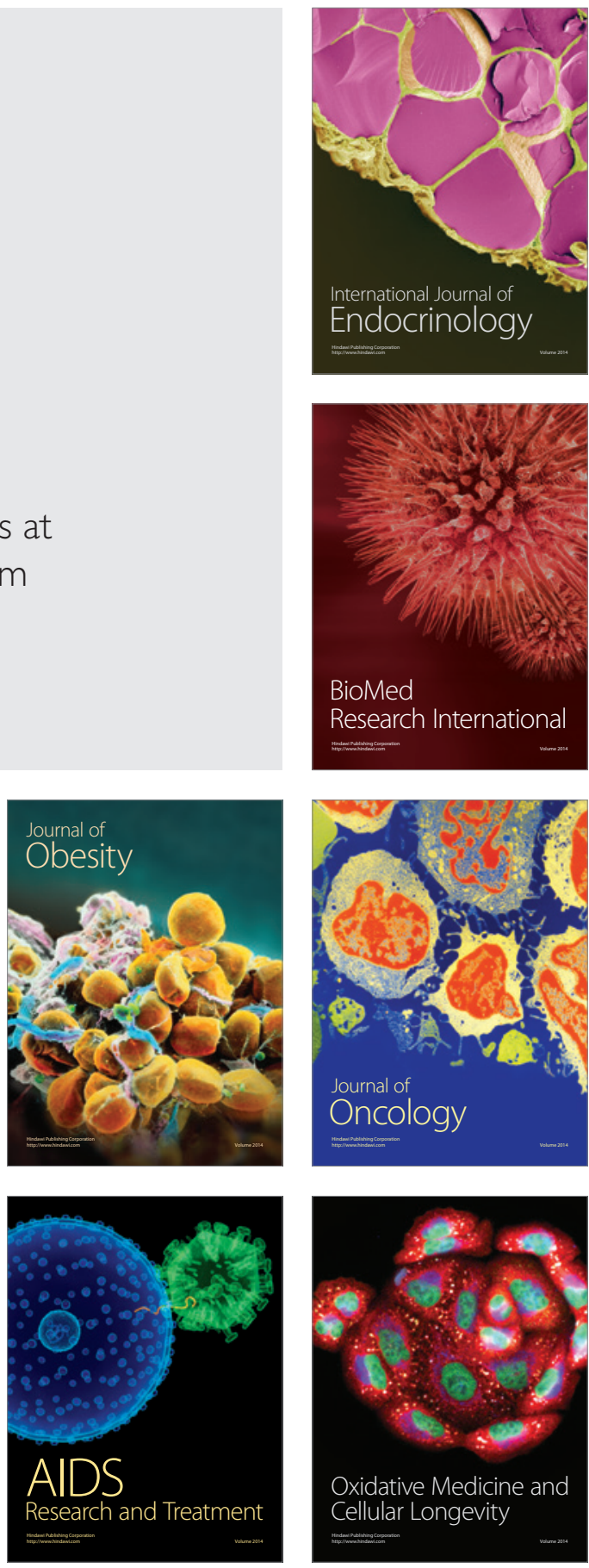